United States

Department of the Interior

Geological Survey

A proposed streamflow-data program for Arizona

By

Otto Moosburner

Open-file report

$70-231$

Tucson, Arizona

August 1970 


\section{CONTENTS}

Page

Abstract........................... 1

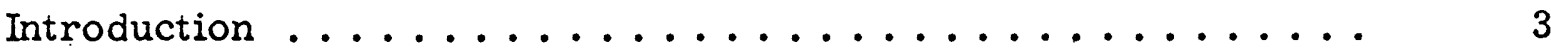

Physical and hydrologic description of Arizona . . . . . . . . 5

Description of the streamflow program and its goals ....... 7

Data for current use $\ldots \ldots \ldots \ldots \ldots \ldots \ldots$

Data for planning and design $\ldots \ldots \ldots \ldots \ldots$

Data needed to define long-term trends . . . . . . . . . 11

Data on stream environment ............... 14

Evaluation of existing data $\ldots \ldots \ldots \ldots \ldots \ldots \ldots$

Data for current use................... 15

Data for planning and design $\ldots \ldots \ldots \ldots \ldots \ldots$

Evaluation of data for natural flow systems ....... 16

Streamflow characteristics . . . . . . . . 17

Physical and climatic basin characteristics ..... 18

Regression analysis ............... 20

Evaluation of data for regulated-flow systems . . . . . 26

Data needed to define long-term trends ........... 27

Data on stream environment $\ldots \ldots \ldots \ldots \ldots \ldots \ldots$

Alternate methods of transferring streamflow data . . . . . . 28

The proposed program .................. 30 
The proposed program-Continued

Data for current use .................

Data for planning and design $\ldots \ldots \ldots \ldots \ldots \ldots$

Principal streams having natural flow . . . . . . .

Minor streams having natural flow ..........

Streams having perennial flow ............

Principal and minor streams having regulated flow ...

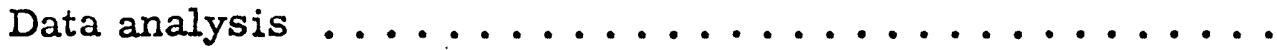

Data needed to define long-term trends $\ldots \ldots \ldots \ldots \ldots$

Data on stream environment $\ldots \ldots \ldots \ldots \ldots \ldots \ldots$

Gaging stations for proposed program ...........

Appendix-Basic data. ..................

References cited $\ldots \ldots \ldots \ldots \ldots \ldots \ldots \ldots$ 


\section{ILLUSTRATIONS}

Page

Figure 1-5. Maps showing:

1. Arizona's water provinces ..........

2. Areas in Arizona where principal stre amflowgaging stations are defined in relation to drainage basin $\ldots \ldots \ldots \ldots \ldots$

3. Regions in Arizona where regression analyses have been made ..............

4. Arizona streams having significant perennial flow ...............

5. Locations of existing and proposed streamflowgaging stations in Arizona ........... 


\section{TABLES}

Page

Table 1. Framework for design of data-collection program ..

2. Standard error in statistical streamflow characteristics for 10 years and 25 years of record at gaging stations in Arizona . . . . . . .

3. Selected regression equations and standard errors for regions analyzed in Arizona . . . . . . . .

4. Comparison of standard errors in station data and in regression results $\ldots \ldots \ldots \ldots \ldots$

5. Proposed long-term stations .............

6. Current-use gaging stations ............

7. Selected Arizona statistical streamflow characteristics used in regression analyses . . . .

8. Physical and climatic characteristics of drainage basins ................

9. Existing and proposed streamflow-gaging stations .. 


\title{
A PROPOSED STREAMFLOW-DATA PROGRAM FOR ARIZONA
}

\section{By}

Otto Moosburner

\begin{abstract}
An evaluation of the streamflow data in Arizona was made to provide guidelines for planning future programs. The basic goals in the evaluation procedure were (1) to define the long-term objectives of the streamflow-data program, (2) to examine and analyze the available data to determine which goals have already been met, and (3) to consider alternate programs and techniques to meet the remaining goals. A regression analysis, using selected streamflow characteristics as dependent variables and physical and climatic characteristics as independent variables, was only partially successful in attaining the goals of the study. The regression method may be more successful in the future if an adequate sample of long-term streamflow records in presently ungaged areas is obtained. In the interim period, alternate methods of transferring information to an ungaged site will be
\end{abstract}


considered. Most of the methods require some information at the ungaged site and gaging-station records to define a specific relation. A streamflow-data program based on the guidelines developed in this study is proposed. 


\section{INTRODUCTION}

The streamflow program of the U.S. Geological Survey in Arizona has evolved through the years as Federal and State interests in the surface-water resources have increased and as funds for operating the stream-gaging-station network have become available. The first measurements of river stage and discharge were made in the 1870's in the Gila River basin by the Federal government and several private companies. The Geological Survey began stream gaging in the State in 1889, and cooperation with the State of Arizona began in 1912. The network expanded slowly, and, by 1919, 24 stations were being maintained, 20 of which were equipped with water-stage recorders. Beginning in 1924 a large increase in State appropriations allowed installation of several additional stations; by 1928, 43 'stations were being maintained. In 1928 the principal stations on the main stem of the Colorado River were considered paramount to the Federal interest, and, since that time, these stations have been operated using Federal funds. Cooperative funds were not available from the State in 1934-35, but the Salt River Valley Water Users' Association-an agency that needs records for the Salt and Verde Rivers and Tonto Creek for use in their projects - cooperated in the maintenance of stations on the streams and somewhat filled the financial void. Toward the end of the depression, the number of stations was increased, and, by 1939,54 of the 58 stations were equipped with recorders. 
In recent years, especially since 1950, many gaging stations have been installed and operated in cooperation with the Arizona State Land Department and the Salt River Valley Water Users' Association as part of a long-range plan to manipulate vegetation in an attempt to increase runoff. Other gaging stations have been added to the network as a part of the flood-control programs in Maricopa and Pima Counties. A crest-stage partial-record network was begun in 1962. The purpose of the program is to define characteristics of peak flows from small drainage areas. At the present time (1970), 170 gages have been installed in the network; 56 of the gages are equipped with floodhydrograph recorders.

The increasing cost of operation, the restraints on funds and manpower, and the need for a greater variety of hydrologic data have necessitated an evaluation of the streamflow-data program in order to make efficient use of the available funds and manpower. Therefore, the purpose of this study was to evaluate the present streamflow-data program and to use the evaluation in the design of an efficient program that will produce the types of information needed to best serve Federal and State interests. The basic goals of this study were (1) to define the long-term objectives of the streamflow-data program in quantitative form, (2) to examine and analyze the available data to 
determine which goals have already been met, (3) to consider alternative means for meeting the remaining goals, and (4) to prepare a proposed program of data collection and analysis to meet the remaining goals.

\section{PHYSICAL AND HYDROLOGIC DESCRIPTION OF ARIZONA}

Arizona is characterized by low-altitude deserts and forested high plains and mountains. The annual precipitation ranges from less than 5 inches to more than 30 inches, and the mean annual temperature ranges from less than $45^{\circ} \mathrm{F}$ to more than $70^{\circ} \mathrm{F}$. About half of Arizona receives less than 10 inches of precipitation during an average year.

Arizona has two distinct rainy seasons-July to September and December to March. The precipitation from July to September is characterized by high-intensity local convective storms. The precipitation from December to March is less intense, and storms normally are widespread. At altitudes above 7,000 feet, most of the winter precipitation is in the form of snow.

The occurrence of surface water in Arizona is controlled mainly by the geology and physiography of the three water provinces the Basin and Range lowlands province, the Central highlands province, and the Plateau uplands province (fig. 1). The Basin and Range lowlands 


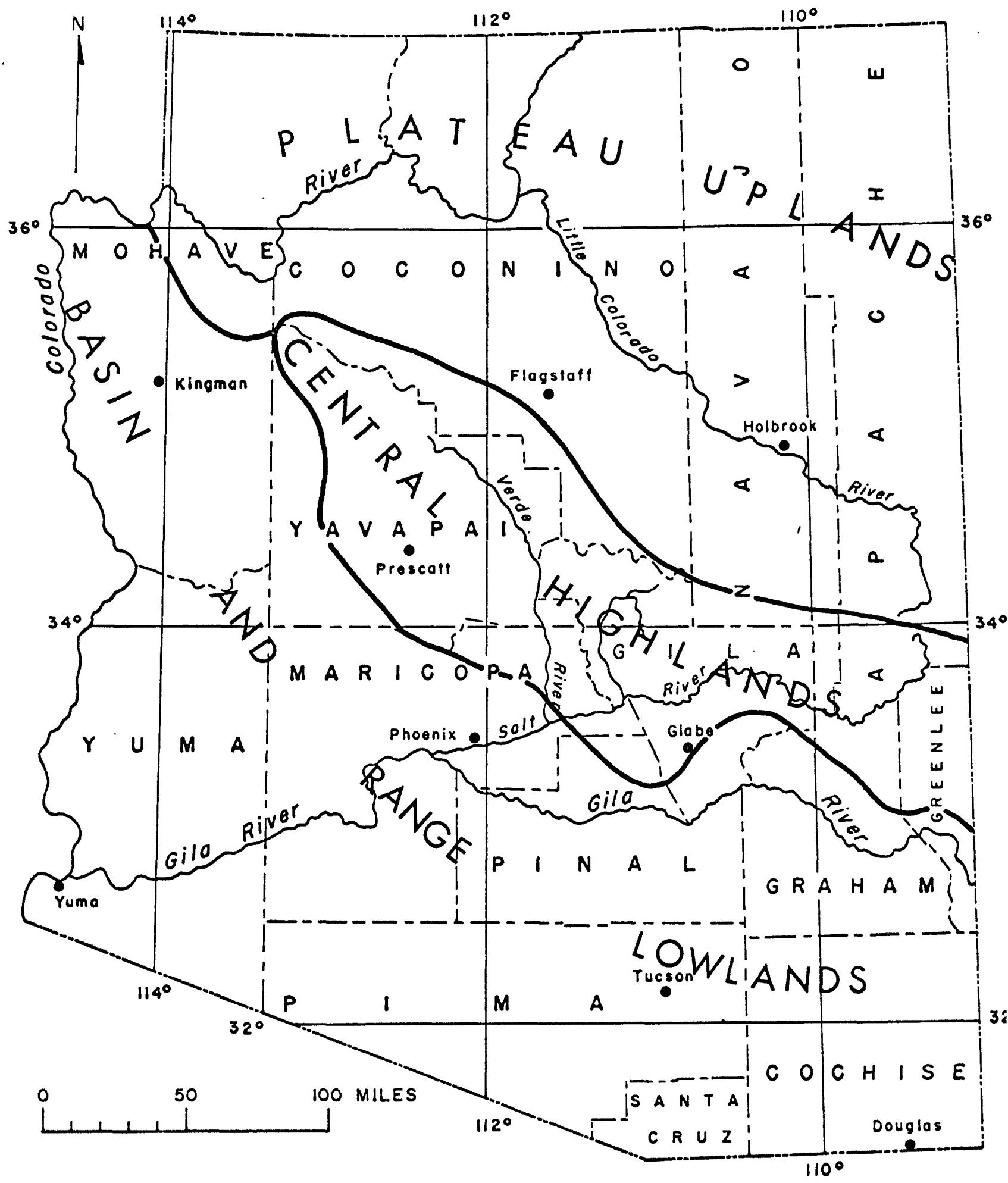

Figure 1.--Arizona's water provinces. 
is characterized by isolated mountain blocks separated by broad alluvial-floored basins. Rugged topography characterizes the Central highlands, and the vegetative cover is sparse to dense. The topography of the Plateau uplands is less rugged than that of the Central highlands; warped and tilted sedimentary formations are typical of the area.

Most of the runoff in Arizona originates in the Central highlands due to winter storms and snowmelt from these storms. Average annual runoff from the higher altitudes may be 10 inches or more, but the average annual runoff for the province is less than 2 inches. Most of the runoff in the other two provinces is due to high-intensity convective storms in the summer months. Average annual runoff in most of the Basin and Range lowlands and the Plateau uplands is less than 1 inch and is highly variable from year to year.

\section{DESCRIPTION OF THE STREAMFLOW PROGRAM AND ITS GOALS}

Streamflow data are needed for planning, design, and operation of projects, for management of the water resources, and for flood control. The needed information may be obtained through a combination of data collection and analysis; however, the data to be collected and the applicable methods of analysis depend on the hydrology of the area, the specific goals of the program, and the cost that can be justified for this 
purpose. The overall objective of a surface-water data program is to provide the data of specified accuracy at any site on any stream. The framework for design of such a program is shown in table 1 . The following paragraphs describe the Arizona surface-water program and the specific goals in terms of the four types of data required.

\section{Data for Current Use}

Data for current use-day-by-day decisions on water management, assessment of water availability, management of water quality, forecast of water hazards, and the surveillance necessary to comply with legal requirements - are commonly obtained by operating a gaging station at a site on a stream for which the information is needed. This element of the streamflow program is not subject to design but changes in response to needs. The goal for this type of data is to provide the particular information needed at specific sites for current use. Accuracy goals at a given site are governed by the use of the data. Higher than usual accuracy can be obtained by intensive observation or by more sophisticated instrumentation.

\section{Data for Planning and Design}

Data used in planning and design are commonly the statistical characteristics of streamflow, such as mean discharge, flood peaks of

$$
\text { (p. } 10^{-8-} \text { follows) }
$$


10-, 25-, or 50-year recurrence intervals, flood volumes of 1-, 3-, or 7-day duration for different recurrence intervals, and 7-day low flows of 2- and 20-year recurrence intervals. These and other statistical characteristics can be obtained from gaging-station records. Although a long period of record is desirable for defining statistical streamflow characteristics at a site, it is not feasible to collect records at every site. Many records are needed to provide information that can be transferred from gaged sites to ungaged sites or to sites where little streamflow data are available. Information for natural flow streams may be obtained by relating flow characteristics to physical and climatic basin characteristics, by relating a short period of record to a longer one, or by interpolating between gaged points on a stream.

The definition of flow characteristics of a regulated stream often is complicated by changes in the regulation during the period of record. Frequently, it is not possible to obtain a long period of record under one condition of development. Transference of flow characteristics from one point to another on a regulated stream is difficult because the procedures used for natural streams, such as regression or interpolation, do not apply. A systems approach seems to be the most efficient way to define the flow characteristics of regulated streams. The systems approach requires an analytical model of the stream system using 
streamflow records, stage-capacity curves for reservoirs, operating rule curves for the release of water, losses owing to evaporation and seepage, stream-channel geometry, and records of diversions and return flows including ground-water pumpage and aquifer characteristics as inputs. The model and associated data may be used to derive homogeneous data for natural and regulated conditions.

Planning and design data are used to define streamflow characteristics at ungaged sites to an accuracy that is equivalent to 25 years of record for principal streams and 10 years of record for minor streams (table 2). In this report streamflow-gaging stations are defined as principal or minor, depending on drainage area and region (fig. 2). Percent accuracy, corresponding to the stated goals, depends on the variability of the flow characteristics being considered.

\section{Data Needed to Define Long-Term Trends}

Data needed to define long-term streamflow trends can be obtained only by operating gaging stations indefinitely on a few natural flow streams. The records from these gaging stations will either affirm that the characteristics defined from the present records are good estimates of the long-term characteristics, or the records will provide a basis for adjusting the short-term characteristics. A few gaging stations on streams that are expected to be relatively free of manmade changes in the flow regimen should be operated indefinitely. 
Table 2. --Standard error in statistical streamflow characteristics for 10 years and 25 years of record at gaging stations in Arizona

\begin{tabular}{l|c|c}
\hline \multirow{2}{*}{ Statistical streamflow characteristics } & \multicolumn{2}{c}{$\begin{array}{c}\text { Standard error } \\
\text { (percent) }\end{array}$} \\
\cline { 2 - 3 } & $\begin{array}{c}10 \text { years of } \\
\text { record }\end{array}$ & $\begin{array}{c}25 \text { years of } \\
\text { record }\end{array}$ \\
\hline Mean annual discharge & 33 & 21 \\
Standard deviation of annual discharge & 22 & 14 \\
Mean monthly discharge (average) & 65 & 41 \\
Standard deviation of monthly discharge & 22 & 14 \\
(average) & 40 & 25 \\
Seasonal discharge (July-September) & 60 & 37 \\
50-year flood & 60 & 37 \\
7-day 50-year high flow & 18 & 12 \\
7-day 2-year low flow (perennial) & 29 & 18 \\
7-day 20-year low flow (perennial) & & \\
\hline
\end{tabular}


Data on Stream Environment

The environment affects the occurrence and use of streamflow; stream-environment data are especially useful in evaluating water use for recreation, waste disposal, and conjunctive surface-water and groundwater supplies. The data also are necessary in planning for the preservation of the aesthetic character of water features and in planning flood-plain development. The long-range goals for using this type of data in Arizona are given below.

1. Determination of streamflow depletion and ground-water recharge.

2. Definition of flood-plain limits for floods of different magnitudes and frequencies.

3. Definition of flood profiles along principal stream channels.

4. Surveys of traveltime of solutes in stream channels.

5. Description of channel changes in response to flow.

6. Reconnaissance studies of the streamflow and stream-channel parameters that are related to the use of the stream for recreation; the parameters are velocity, depth, bank vegetation, bed material, water temperature, water quality, and channel accessibility.

7. Research studies of the effects of manmade changes on the environment in relation to streamflow. 


\section{EVALUATION OF EXISTING DATA}

All available data were analyzed in relation to the program goals. A separate evaluation was made for each of the four types of data-data for current use, data for planning and design, data needed to define long-term trends, and data on stream environment.

\section{Data for Current Use}

In Arizona most of the streamflow-gaging stations, about 70 percent, are operated to provide data for current use. The assumptions are that the need for this type of data is being satisfied and that this part of the program will be modified as requirements change. The 115 streamflow-gaging stations operated to satisfy the need for current data in Arizona and the principal uses of the data are given in table 6.

\section{Data for Planning and Design}

The statistical characteristics of streamflow are defined by streamflow measurements, regionalization by analytical methods, systems studies, or any combination of the three. The following sections on the evaluation of this type of data are according to the framework for design of a data-collection program (table 1). 
The purpose of this evaluation is to determine how accurately the statistical streamflow characteristics - listed as goals in table 1can be defined by regionalization of the available data. At the present time (1970), the most effective way known to define statistical streamflow characteristics on a broad scale is to relate them to basin characteristics in equations developed by use of multiple-regression techniques applied to past data. Once the equation and its constants are defined, streamflow characteristics for a specific stream in a given basin can be computed by substituting the appropriate values for the basin characteristics in the formulas.

Most of the 104 streams used in the analyses have unregulated flow and 8 or more years of record, although several streams having less than 8 years of record were used to supplement otherwise incomplete areal coverage. Both minor and principal streams are included, and records were not adjusted to a base period. Because of varying degrees of regulation and the brevity of some records, it was not possible to define all the flow characteristics from each record. Streamflow data collected before regulation by major reservoirs were used, and streamflow characteristics were defined for the study. Streamflowgaging stations used in the regression analysis are given in table 7. 
Streamflow characteristics. --Streamflow characteristics at gaging stations include the full range of streamflow-high flow, medium flow, and low flow - and selected characteristics are given in table 7. The following streamflow characteristics have been defined and represent the data required for planning and design in Arizona:

1. Mean-flow characteristics are described by the means of the annual means, the means of records for the warm season, July through September, and the means for each calendar month.

2. Flow-variability characteristics are represented by the standard deviations of the annual and monthly means and the coefficient of variation of annual mean flows.

3. Flood-peak characteristics are represented by discharges determined by Type III log-Pearson flood-frequency analyses for recurrence intervals of $2,5,10,25$, and 50 years.

4. Flood-volume characteristics represent the annual highest average flow for 1-day, 3-day, and 7-day periods for recurrence intervals of 2,10 , and 50 years.

5. Low-flow characteristics are represented by the annual minimum 7-day mean flows at 2- and 20-year recurrence intervals. If values are indicated for a streamflow site, the stream is perennial or nearly perennial. 
Physical and climatic basin characteristics. --Values of the physical and climatic basin characteristics for each of the 104 gaging stations used in the regression analyses are given in table 8. The physical and climatic basin characteristics defined for this study are:

1. Drainage area (A), in square miles, as used in the recent U.S. Geological Survey streamflow reports.

2. Main-channel slope (S), in feet per mile, determined from elevations at points 10 percent and 85 percent of the distance along the channel from the gaging station to the divide.

3. Main-channel length (L), in miles, from the gaging station to the basin divide.

4. Mean basin elevation (E), in feet above mean sea level, as measured by laying a grid over a 1:250,000 Army Map Service map or a 7-1/2-minute or 15-minute U.S. Geological Survey topographic map to determine the elevation at each grid intersection and to average those elevations. The grid spacing was selected to give at least 25 intersections within the basin boundary.

5. Shape factor, dimensionless, determined by dividing the square of the main-channel length by the drainage area.

6. Aspect is a measure of main-channel flow direction, in degrees, and was determined as the angle between north and the line defined by the main-channel basin divide and the gaging station. 
7. Soil index, dimensionless, is an index to soil-infiltration capacity and is based on information supplied by the U.S. Soil Conservation Service from information on soil type, cover, and agricultural practices.

8. Latitude, to the nearest 0.1 degree, measured from available maps; figures given represent the approximate geographical center of the drainage basin.

9. Longitude, to the nearest 0.1 degree, measured from available maps; figures given represent the approximate geographical center of the drainage basin.

10. Mean annual precipitation, in inches, determined from an isohyetal map prepared by the University of Arizona (1965). The map was prepared on the basis of precipitation data and physiographic correlations.

11. Mean seasonal precipitation (May-September), in inches, determined from an isohyetal map prepared by the University of Arizona (1965). The map was prepared on the basis of precipitation data and physiographic correlations.

12. The maximum 6 -hour point rainfall, $I_{6,10}$, having a recurrence interval of 10 years (10-year 6-hour precipitation), expressed in inches. These values were determined using the U.S. Weather Bureau (1967a) map. 
13. The maximum 24-hour point rainfall, $\mathrm{I}_{24}, 10$, having a recurrence interval of 10 years, expressed in inches. These values were determined using the U.S. Weather Bureau (1967b) map.

14. The maximum 6 -hour point rainfall, $I_{6,50}$, having a recurrence interval of 50 years, expressed in inches. These values were determined using the U.S. Weather Bureau (1967c) map.

15. The maximum 24-hour point rainfall, $\mathrm{I}_{24}, 50$, having a recurrence interval of 50 years, expressed in inches. These values were determined using the U.S. Weather Bureau (1967d) map.

16. Mean annual snowfall, in inches, derived from a map drawn on the basis of a multiple regression of mean annual snowfall at long-term Weather Bureau stations and altitude, latitude, and longitude.

Regression analysis. --Each of the streamflow characteristics was related to the physical and climatic basin characteristics by multiple regression using the equation:

$$
Y=a A^{b} B^{c} C^{d},
$$

where $\mathrm{Y}$, the dependent variable, is a streamflow characteristic, such as mean annual flow; $A, B$, and $C$, the independent variables, are physical and climatic basin characteristics, such as drainage area or precipitation; and a, b, c, and d are coefficients obtained by regression. 
Some of the streamflow characteristics given in table 7 are extremely correlative and, therefore, were not used in the regression analysis. All physical and climatic basin characteristics, except length, latitude, longitude, $I_{6,10}, I_{6,50}$, and $I_{24,50}$, were used in one or more of the initial regression analyses.

After the computation of an initial regression equation by a digital computer, the coefficients were tested for statistical significance, and the characteristics, which were found insignificant at a confidence level of 95 percent, were dropped. Then, the regression equation using only the significant parameters was determined, and the standard error was computed.

Residuals - the differences between the values of streamflow characteristics determined by regression analyses and the values of the characteristics determined from the gaging-station records-were plotted on a map of Arizona in order to determine any regional variations. The part of the State having sufficient streamflow data for regression analysis was divided into two regions, and additional streamflow regressions were computed for both regions (fig. 3). A sample of the regression results is given in table 3, and the results are compared with the accuracy goals in table 4 for streams having 10 and 25 years of record.

$$
(p .24 \text { follows })
$$


Table 4.--Comparison of standard errors in station clata and in regression results

\begin{tabular}{|c|c|c|c|c|}
\hline \multirow{3}{*}{$\begin{array}{l}\text { Statistical streamflow } \\
\text { characteristics }\end{array}$} & \multicolumn{4}{|c|}{$\begin{array}{c}\text { Standard error } \\
\text { (percent) }\end{array}$} \\
\hline & \multicolumn{2}{|c|}{$\begin{array}{l}\text { Station } \\
\text { data }\end{array}$} & \multicolumn{2}{|c|}{$\begin{array}{l}\text { Regression } \\
\text { results }\end{array}$} \\
\hline & $\begin{array}{l}10 \text { years } \\
\text { of record }\end{array}$ & $\begin{array}{l}25 \text { years } \\
\text { of record } \\
\end{array}$ & $\begin{array}{c}\text { Region } \\
1 \\
\end{array}$ & \begin{tabular}{|c|} 
Region \\
2 \\
\end{tabular} \\
\hline Mean annual discharge & 33 & 21 & 55 & 33 \\
\hline $\begin{array}{l}\text { Standard deviation of } \\
\text { annual discharge }\end{array}$ & 22 & 14 & 48 & 33 \\
\hline $\begin{array}{l}\text { Mean monthly discharge } \\
\text { (average) }\end{array}$ & 65 & 41 & 145 & 131 \\
\hline $\begin{array}{l}\text { Standard deviation of } \\
\text { monthly discharge } \\
\text { (average) }\end{array}$ & 22 & 14 & 152 & 129 \\
\hline $\begin{array}{l}\text { Seasonal discharge (July- } \\
\text { September) }\end{array}$ & 40 & 25 & 61 & 60 \\
\hline 50-year flood & 60 & 37 & 97 & 54 \\
\hline 7-day 50-year high flow & 60 & 37 & 74 & 47 \\
\hline $\begin{array}{l}\text { 7-day 2-year low flow } \\
\text { (perennial) }\end{array}$ & 18 & 12 & 136 & 114 \\
\hline $\begin{array}{l}\text { 7-day } 20 \text {-year low flow } \\
\text { (perennial) }\end{array}$ & 29 & 18 & 256 & 261 \\
\hline
\end{tabular}


The standard errors in the regression equations for region 2 are about equivalent, or smaller, than those for 10 years of record at a site for mean annual discharge, 50-year flood, and 7-day 50-year high flow (table 4); values for these streamflow characteristics can be estimated by using the appropriate equations for region 2. Goals for other streamflow characteristics in region 2 are not met by the regression equations. The accuracy goals in region 1 and the rest of the State were not satisfied.

Regionalization of streamflow characteristics in most of the State has not been possible for the following reasons:

1. A relatively small number of streamflow records is available outside the Central highlands province, and most of the records are of short duration.

2. Physical and climatic basin characteristics are poorly defined. Many of these characteristics have been derived by multiple regression because of the scarcity of data. Measures of the effects of soils and geology on streamflow are almost nonexistent.

In most of the State the regression method, in time, may yield results equivalent to 10 years of record at a streamflow-gaging station, but the method probably will not be improved sufficiently to provide an accuracy equivalent to 25 years of record. In the meantime, alternate methods of transferring flow characteristics to ungaged sites may be used. 


\section{Evaluation of Data for Regulated-Flow Systems}

The goals of the streamflow program are more difficult to attain for the regulated streams than for the unregulated streams in Arizona because the technique of regionalization does not apply, the characteristics are not necessarily stationary in time, and a meaningful correlation seldom exists between flows at two sites if at least one of the flows is regulated. A systems approach may be used to define the characteristics of regulated flow under different types of regulation or under the condition of natural flow. Systems studies for all regulated streams in Arizona will require a major effort. The present evaluation is limited to the identification of regulated streams and to the brief description of the approach that could be used.

In Arizona and along the boundaries of Nevada, California, and Mexico the Colorado River is completely regulated. The Gila River below Coolidge Dam is almost completely regulated by storage in Coolidge Reservoir and by storage in its main tributaries - the Salt and the Agua Fria Rivers. Bill Williams River below Alamo Dam has been partly regulated since completion of the dam in 1968.

The regulation of the major streams is almost complete. All the major dams - except Painted Rock Dam on the Gila River and Alamo Dam on the Bill Williams River - were constructed to store irrigation water, and in most years all water released is used for this purpose. 
The Gila River and its main tributaries are dry below the last diversions, except during periods of tributary inflow below the dams and diversions or at infrequent times when water must be released from storage. No water has spilled over Coolidge Dam since its completion in 1928. Since the completion of the reservoir system on the Salt River above the Verde River in 1930, spillage has occurred three times. The reservoir system on the Verde River has spilled over twice since its completion in 1945. Spillage from Lake Pleasant on the Agua Fria River has occurred three times since the construction of Waddell Dam in 1928.

The statistical characteristics of regulated streamflow can be computed from synthesized records. A longer homogeneous record at a gage site or any other point on a regulated stream can be computed by developing a flow-storage model of the reservoir and the channel and by using the natural flow records and the rule curve for operation of the reservoir as inputs to the model.

\section{Data Needed to Define Long-Term Trends}

At the present time (1970), only one station-Wet Bottom Creek near Childs - is designated as a hydrologic bench-mark station that is to be operated indefinitely. Because of the varying climatic and hydrologic conditions in Arizona, additional stations should be established and are proposed in a subsequent section of this report. 


\section{Data on Stream Environment}

Streamflow depletion in the Tucson basin has been evaluated by Burkham (1970), and some of the results have been incorporated by Anderson (1970) in an electrical-analog model depecting recharge to the ground-water basin. Water samples are collected at 20 gaging stations and at many miscellaneous sites for chemical analysis. In addition, intensive sampling of water in the canals and diversions near the Colorado River is conducted to meet legal requirements. Streamflow sediment data are collected at 11 gaging stations and at several miscellaneous sites. Water temperatures are monitored continuously at these sites and are measured periodically at all gaging stations and some miscellaneous sites. Flood-prone areas along the Gila and Santa Cruz Rivers and along some other streams have been identified, and the work is continuing. Channel surveys have been made at many sites in connection with indirect determinations of peak flows for unusual floods.

\section{ALTERNATE METHODS OF TRANSFERRING STREAMFLOW DATA}

The collection of additional streamflow data ultimately will lead to better definition of streamflow characteristics by regression analysis. In the interim period, alternate methods of transferring 
information to an ungaged site will be considered. Most of the methods require some information at the ungaged site and gaging-station records to define a specific relation.

Moore (1968) has shown that mean annual flow may be estimated using the width and depth of the lower section of the stream channel. Different relations were developed for perennial and ephemeral streams. At the present time (1970), these relations provide a means of estimating the mean annual flow at a site, and better definition of the relations through research may lead to more exact definition.

Riggs (1969) showed that the mean annual flow at a site can be estimated by measuring the discharge at the site about the middle of each calendar month for a water year if concurrent correlation can be established with a nearby gaging station. This method may have particular application in areas where runoff is from snowmelt.

The use of partical-record stations to define low-flow characteristics at sites is described by Riggs (1965). A partialrecord station is one at which enough base-flow measurements are available to define an adequate relation with concurrent flows at a nearby gaging station. The frequency characteristics of the low flows at partial-record stations can be determined from the relation of concurrent flows and the historical record at the gaged site. In Arizona most streams are ephemeral; a generalized map showing reaches 
having perennial flow may be used to locate sites at which low-flow characteristics may be determined by correlation with concurrent flows at gaged sites (fig. 4).

Patterson and Somers (1966) provide a means of estimating flood peaks of different recurrence intervals in parts of Arizona. Using their procedure, flood-peak characteristics can be determined from the size of drainage area at an ungaged site. The standard errors inherent in using this method are not known.

\section{THE PROPOSED PROGRAM}

The results of this study indicate that the existing program does not provide sufficient data to satisfy the needs of the proposed program. The information obtained during the study has been used in planning a streamflow-data program that eventually will meet the goals for the different types of data. A balance must be maintained between data collection and data analysis for an optimum program to gain a better understanding of the hydrologic system and to enable the future evaluation of the program to meet ever-changing needs and technology.

$$
(p .32 \text { follows })
$$




\section{Data for Current Use}

The operation of the 115 stations that satisfy the current-use data needs should be continued (table 6). Needs should be assessed periodically, and this part of the data-collection network should be modified by the addition or discontinuation of stations as needs change; furthermore, the need for a continuous discharge record at each site should be examined. In some instances a stage record or definition of peak flows may suffice.

\section{Data for Planning and Design}

Only limited success has been attained using regional regression techniques in analyzing data for planning and design. Most of the existing gaging stations and the installation of additional gaging stations in areas where few records are available are necessary in order to have adequate data for planning and design.

\section{Principal Streams Having Natural Flow}

A network of well-spaced gaging stations will provide the data on flow characteristics that are needed for regional definition by regression analysis, that can be transferred to sites for which discharge measurements are available, and that may be used to define relations 
between channel geometry and mean flow or floodflow. All the existing gaging stations on principal streams having natural flow should be continued, except those listed below; the following stations have sufficient periods of record to satisfy the goals of the program.

Station number

Station name

Length of record as of 1970 (in years)

$09-3865.00$

Little Colorado River above Zuni

30

River, near Hunt

09-3880.00 Little Colorado River near Hunt

34

09-3945.00 Little Colorado River at Woodruff

$09-3980.00$

Chevelon Creek near Winslow

$09-4820.00$

Santa Cruz River at Continental

$09-4825.00$

Santa Cruz River at Tucson

65

$09-4858.50$

Rillito Creek near Tucson

62

$09-4865.00$

Santa Cruz River at Cortaro

$09-5125.00$

Agua Fria River near Mayer

30

Additional gaging stations should be established on the following principal streams:

Chinle Wash near Many Farms

Carrizo Wash near mouth

Zuni River near mouth 
Cottonwood Wash below Pueblo Wash, near Winslow

Corn Creek near mouth near Leupp

Havasu Creek near Supai

Trout Creek near mouth

Burro Creek at State Highway 93

Kirkland Creek above Sycamore Creek, near Yava

Bouse Wash near mouth

Santa Cruz River near Tubac

Santa Cruz River at Greens Wash

Big Chino Wash near Seligman

Hassayampa River near Arlington

Tenmile Wash at U.S. Highway 80

San Simon Wash at United States-Mexico border

The discontinued station, Puerco River near Adamana (09-3965. 00), should be reestablished. Each station in the existing and proposed network should be operated for at least 25 years.

The collection of peak-flow data should be continued at all gaging stations. Each year, some effort should be devoted to the measurement of discharge and channel geometry, and the relations used in estimating flow characteristics from discharge measurements and channel geometry measurements should be tested and improved, if possible. 
An equivalent of 10 years of record is needed to meet the goals for minor streams. Because only limited success was achieved by using the regression method, 20 years of record at the gaged sites is recommended. All the existing continuous-record gaging stations should be continued, except those listed below; the following stations have sufficient periods of record to satisfy the goals of the program.

Station number

$09-4815.00$

$09-4840.00$

$09-5045.00$
Station name

Sonoita Creek near Patagonia

Sabino Creek near Tucson

Oak Creek near Cornville
Length of record as of 1970 (in years)

27

Additional continuous-record gaging stations should be established on the following minor streams, most of which are presently equipped with flood-hydrograph recorders or crest-stage gages:

Station

number

$09-3790.30$

Black Mountain Wash near Chinle

09-4011.00 Dinnebito Wash near Oraibi

09-4003.00 Teshbito Wash near Holbrook

\begin{tabular}{|c|}
\hline $\begin{array}{c}\text { Drainage } \\
\text { area } \\
\text { (sq mi) }\end{array}$ \\
\hline
\end{tabular}

81

1963 to present

261

1969 to present

57

1963 to present 
$09-3951.00$

Carr Lake Draw tributary near

1.191964 to present

Holbrook

09-3795.60 El Capitan Wash near Kayenta

5. 881963 to present

09-4005.30 Meteor Wash near Winslow

3. 01963 to present

09-4012.20 Cedar Wash near Cameron

556

1967 to present

09-4038. 00 Bitter Seeps Wash tributary near

2. 851963 to present

Fredonia

Grand Wash near mouth

09-4041.00 Cataract Creek near Grand Canyon 1,200

370

1968 to present

$09-4043.40$

Truxton Wash at Valentine

787

1965 to present

09-4238. 20 Sacramento Wash near Yucca

09-4244. 80 Kirkland Creek tributary near

7.62

1966 to present

Kirkland

09-4285.50 Bouse Wash tributary near Bouse

14. 61963 to present

09-4288.00 Tyson Wash tributary near Quartzsite

13. $7 \quad 1963$ to present

09-5142.00 Waterman Wash near Buckeye

1964 to present

09-5174. 00 Winters Wash near. Tonopah

47. 81962 to present

09-5202.00 Black Gap Wash near Ajo

12.11963 to present

09-5203.00 Alamo Wash tributary near Ajo

.901963 to present

North Bank tributary of Gila between Gila Bend and Yuma

09-5352.00 Sells Wash tributary at Sells

26. 8 . 1962 to present 
The rest of the stations in the partial-record crest-stage network, which was started in 1962 , should be continued until satisfactory regional regression analysis of the flood characteristics can be developed.

\section{Streams Having Perennial Flow}

A network of partial-record low-flow stations should be established on perennial streams. Sufficient base-flow measurements should be obtained at each station to establish concurrent correlation with base flow at a continuous-record gaging station. The network could be concentrated in one part of the State for several years and then shifted to another area.

\section{Principal and Minor Streams Having Regulated Flow}

All principal regulated streams in Arizona are adequately gaged to begin systems studies. The principal regulated streams are the Gila River, the Salt River below Roosevelt Dam, the Verde River below Horseshoe Dam, the Bill Williams River below Alamo Dam, and the Colorado River throughout its course in Arizona.

Many headwater tributaries of principal and minor streams are regulated to an unknown degree by stock ponds and, in recent years, by small recreational lakes. The effect of this regulation on streamflow 
characteristics probably is insignificant for principal streams but may be significant for minor streams. An analysis of the effects of the regulations is beyond the scope of this report.

\section{Data Analysis}

As additional gaging stations are established and longer periods of record become available, regional regression analyses should be attempted in 5 years. Studies of alternate methods of transferring flow characteristics to ungaged sites should be made. Emphasis should be placed on improving relations for estimating flow characteristics from channel geometry and the generalized relations among flow characteristics at different times of the year. Finally, continuous appraisal of the data-collection system should be made with respect to the type of information needed.

\section{Data Needed to Define Long-Term Trends}

Since 1967, one station has been operated to define long-term trends, and the station should be operated indefinitely. Six existing stations and one new station are proposed for long-term operationthree gaging stations will record perennial flow, and five will record ephemeral flow (table 5). The stations were selected to provide areal coverage in the State, a range in size and type of drainage area, a range in type of stream, and a variety of physical and climatic basin characteristics. 
Table 5. --Proposed long-term stations

\begin{tabular}{|c|c|c|c|}
\hline $\begin{array}{l}\text { Station } \\
\text { number }\end{array}$ & Station name & $\begin{array}{c}\text { Drainage } \\
\text { area } \\
\text { (sq } \mathrm{mi}) \\
\end{array}$ & $\begin{array}{l}\text { Period } \\
\text { of } \\
\text { record }\end{array}$ \\
\hline $09-3792.00$ & Chinle Wash near Mexican Water & 3,660 & $\begin{array}{l}1964 \text { to } \\
\text { present }\end{array}$ \\
\hline $09-4014.00$ & Moenkopi Wash near Tuba City & 2,550 & $\begin{array}{l}1941-53 \\
1965 \text { to } \\
\text { present }\end{array}$ \\
\hline $09-4242.00$ & $\begin{array}{l}\text { Cottonwood Wash No. } 1 \text { near } \\
\text { Kingman }\end{array}$ & 143 & $\begin{array}{l}1964 \text { to } \\
\text { present }\end{array}$ \\
\hline $09-4244.50$ & Big Sandy River near Wikieup & 2,800 & $\begin{array}{l}1966 \text { to } \\
\text { present }\end{array}$ \\
\hline $09-4850.00$ & Rincon Creek near Tucson & 44.8 & $\begin{array}{l}1952 \text { to } \\
\text { present }\end{array}$ \\
\hline $09-4891.00$ & Black River near Maverick & 315 & $\begin{array}{l}1962 \text { to } \\
\text { present }\end{array}$ \\
\hline $09-5083.00$ & Wet Bottom Creek near Childs & 37 & $\begin{array}{l}1967 \text { to } \\
\text { present }\end{array}$ \\
\hline $09-5197.50$ & Bender Wash near Gila Bend & 68.8 &.-- \\
\hline
\end{tabular}


Stream-environment data should be collected as needed and as time and funds become available. Special emphasis should be placed on the following:

1. Infiltration and ground-water recharge in losing streams.

2. Traveltime and flow attenuation with emphasis on losing streams.

3. Geomorphology of losing streams.

4. Deliniation of flood-prone areas.

5. Urban hydrology.

6. Chemical quality, sediment, and temperature of streamflow with special emphasis on perennial streams.

7. Analysis and publication of existing data for stream velocities, depths, widths, streambank vegetation, and water temperatures..

\section{Gaging Stations for Proposed Program}

The gaging stations now in operation and those required for the proposed network are given in table 9 in the appendix. The locations of the gaging stations are shown in figure 5. 
APPENDIX BASIC DATA

42 (p.55 follows) 
Anderson, T. W., 1970, Electrical-analog analysis of the hydrologic system, Tucson basin, Arizona: U.S. Geol. Survey WaterSupply Paper 1939-C. (In press.)

Burkham, D. E., 1970, Depletion of streamflow by infiltration in the main channels of the Tucson basin, Arizona: U.S. Geol. Survey open-file report, $80 \mathrm{p}$.

Moore, D. O., 1968, Estimating mean runoff in ungaged semiarid areas: Nevada Water Resources Bull. 36, 39 p.

Patterson, J. L., and Somers, W. P., 1966, Magnitude and frequency of floods in the United States, Part 9, Colorado River basin: U.S. Geol. Survey Water-Supply Paper 1683, 475 p.

Riggs, H. C., 1965, Estimating probability distributions of drought flows: Water and Sewage Works, v. 112, no. 5, p. 153-157. 1969, Mean streamflow from discharge measurements:

Internat. Assoc. Sci. Hydrology Bull. 14, no. 4, p. 95-110. University of Arizona, 1965, Normal annual precipitation-normal May-September precipitation-1931-1960, State of Arizona: Univ. Arizona map.

U.S. Weather Bureau, 1967a, Arizona, 10-year 6-hour precipitation:

U.S. Dept. Commerce map. 1967b, Arizona, 10-year 24-hour precipitation:

U.S. Dept. Commerce map. 
1967c, Arizona, 50-year 6-hour precipitation:

U.S. Dept. Commerce map.

1967d, Arizona, 50-year 24-hour precipitation:

U.S. Dept. Commerce map. 


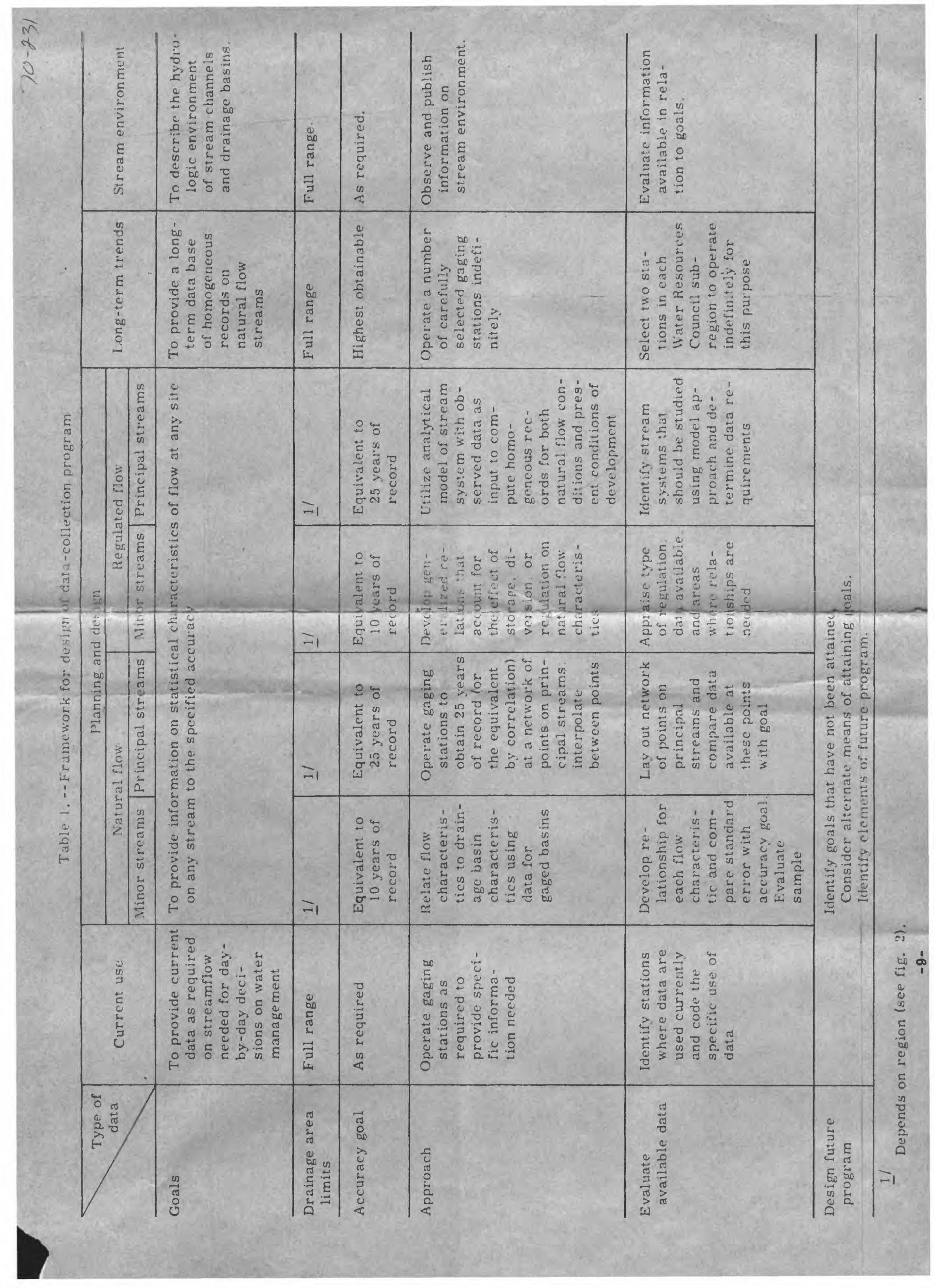



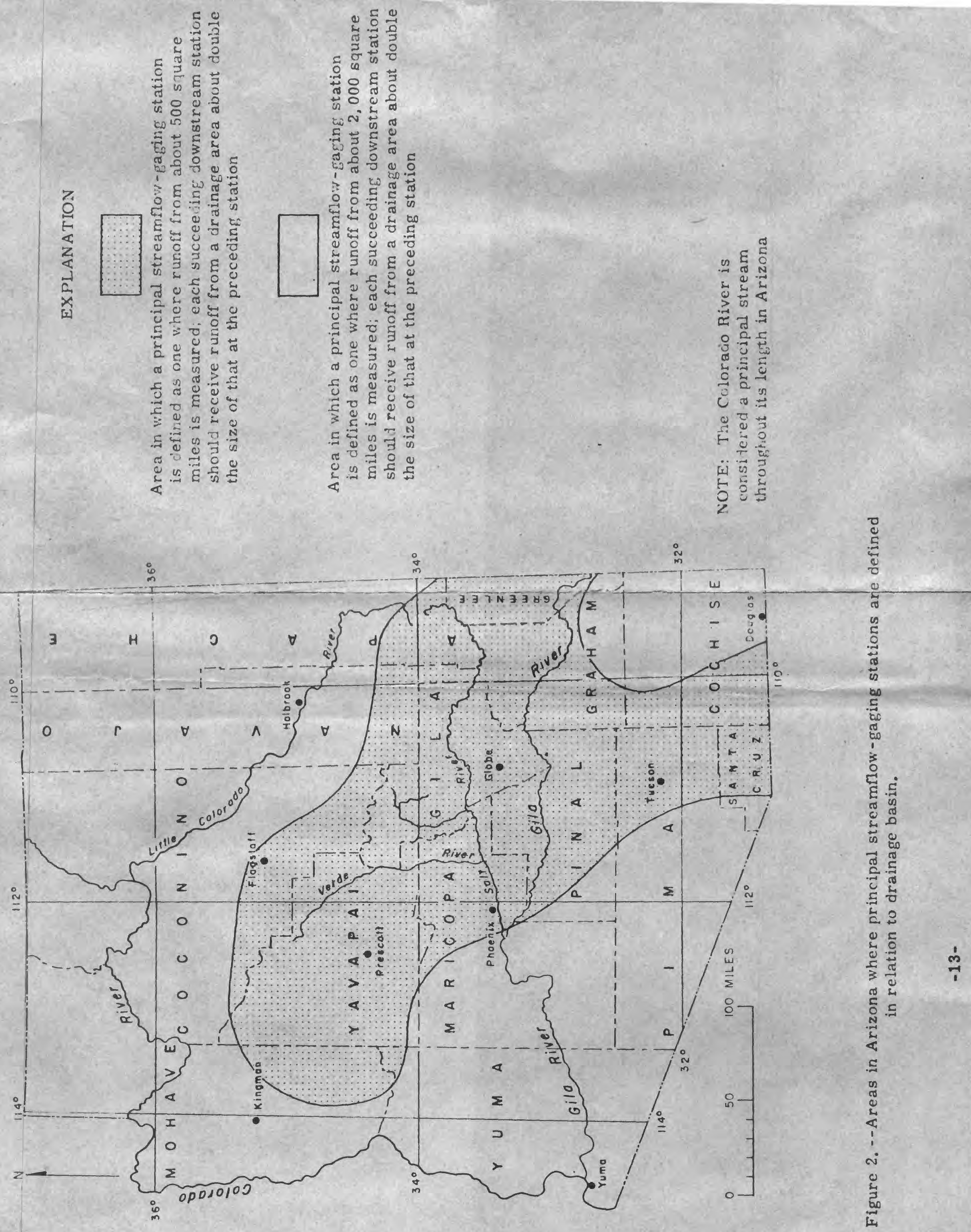


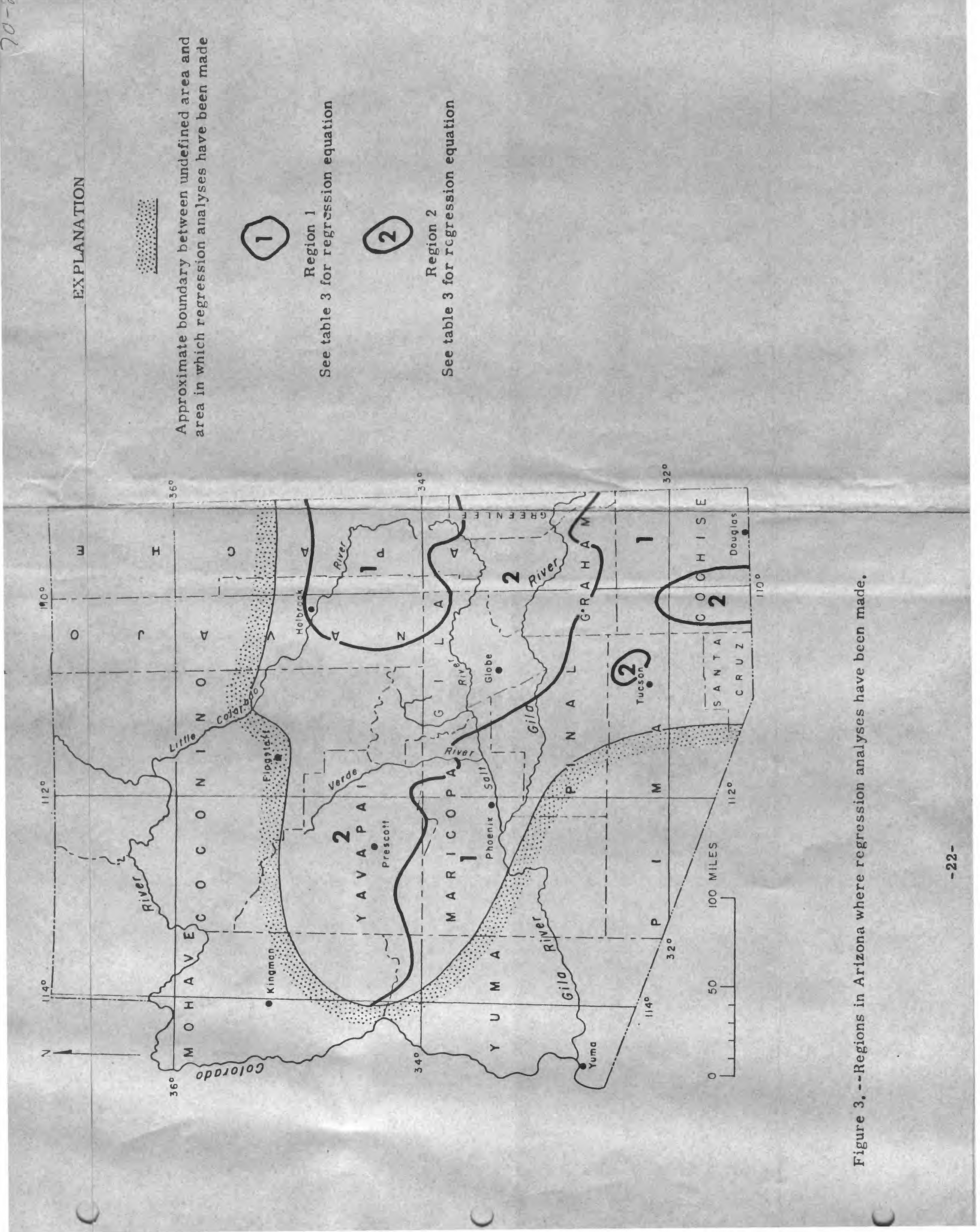




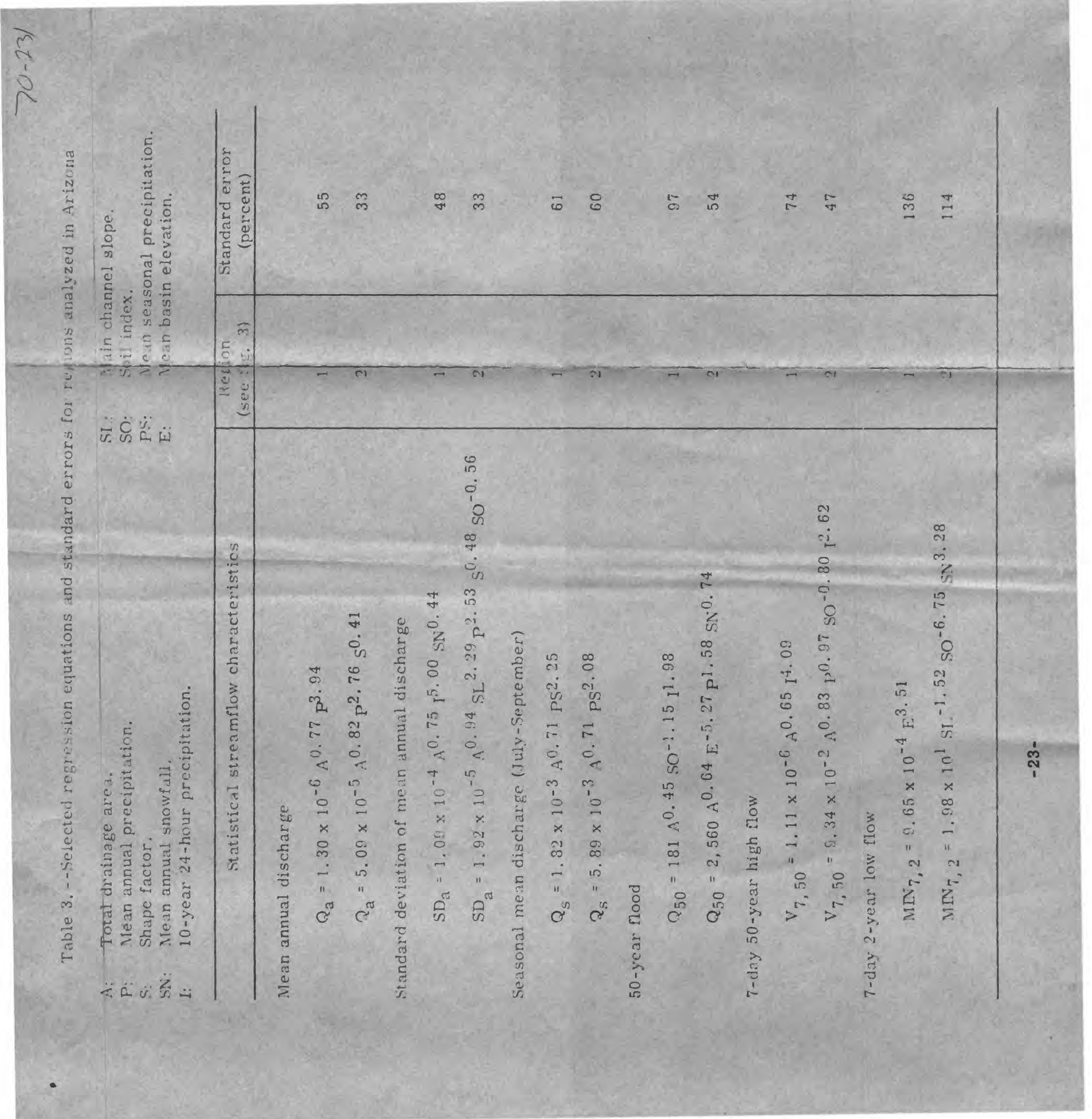




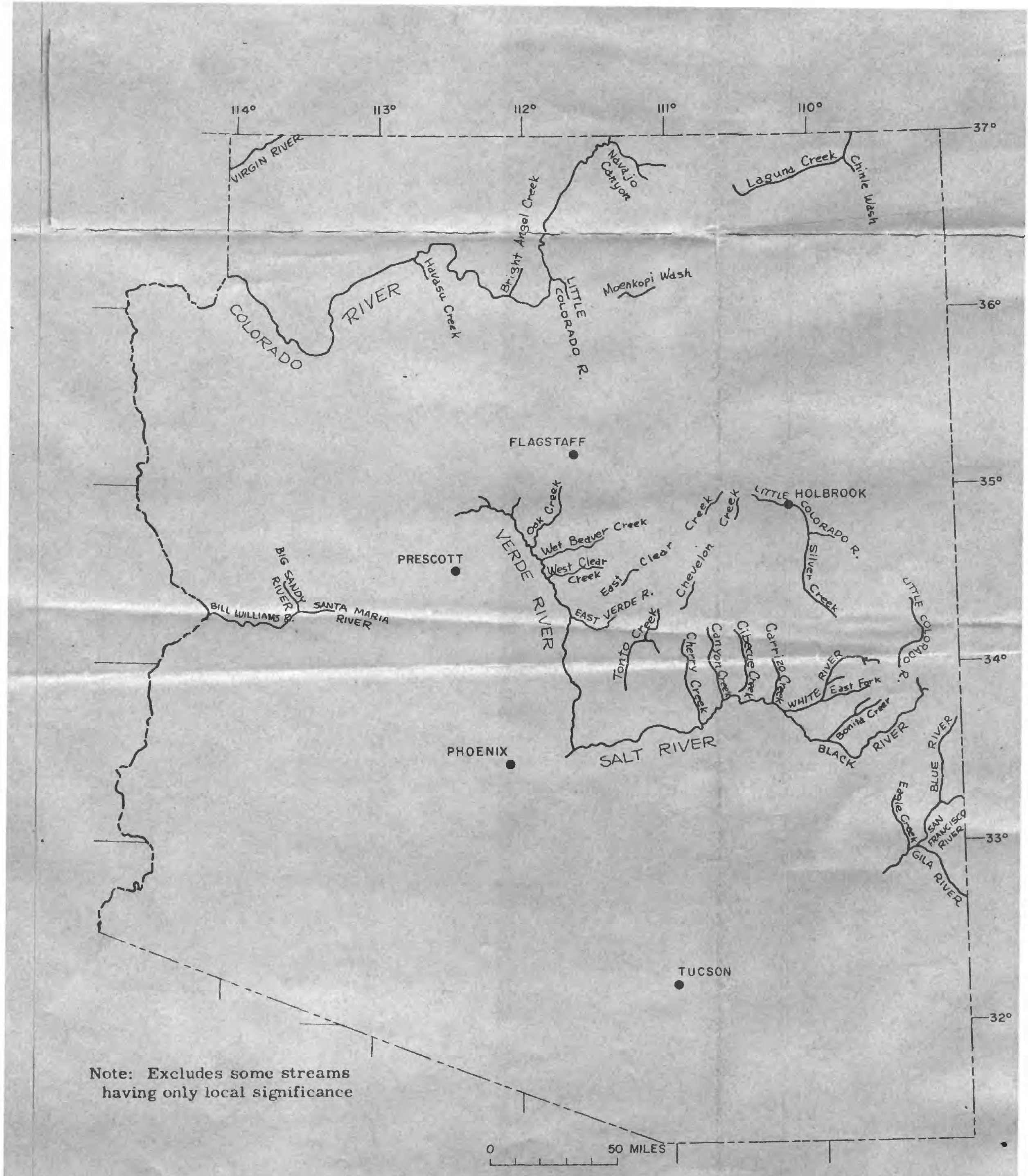

Figure 4. --Arizona streams having significant perennial flow. 


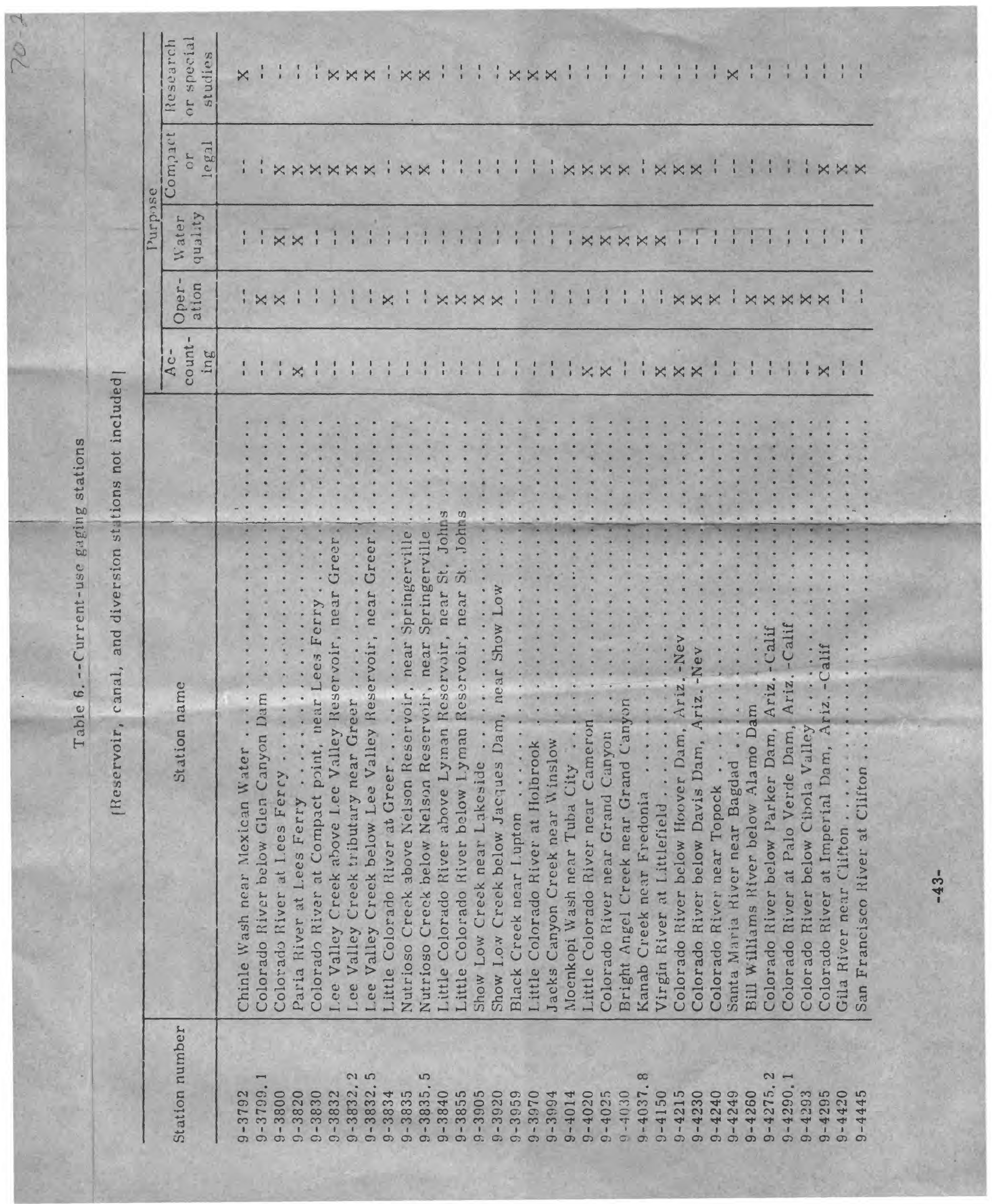




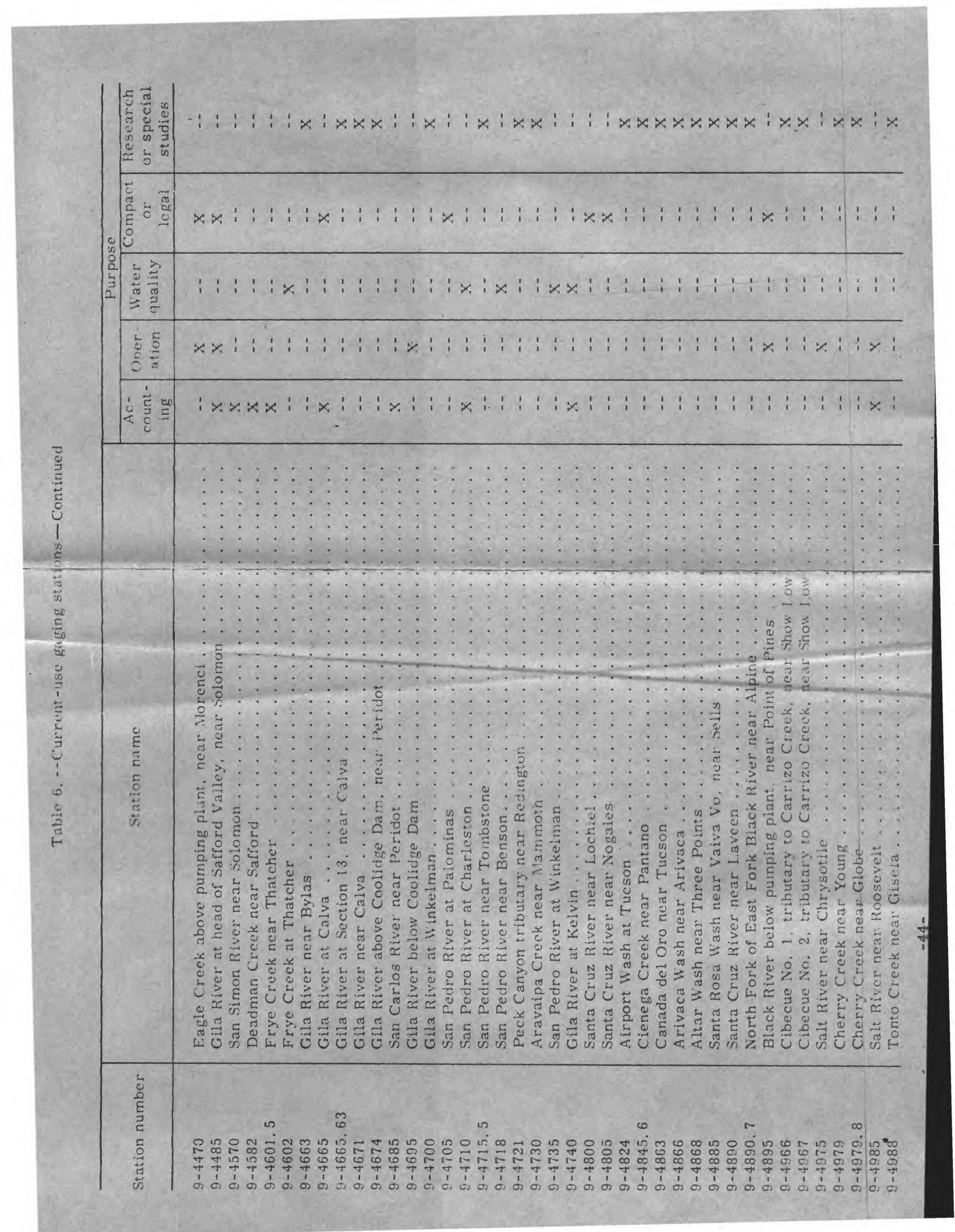




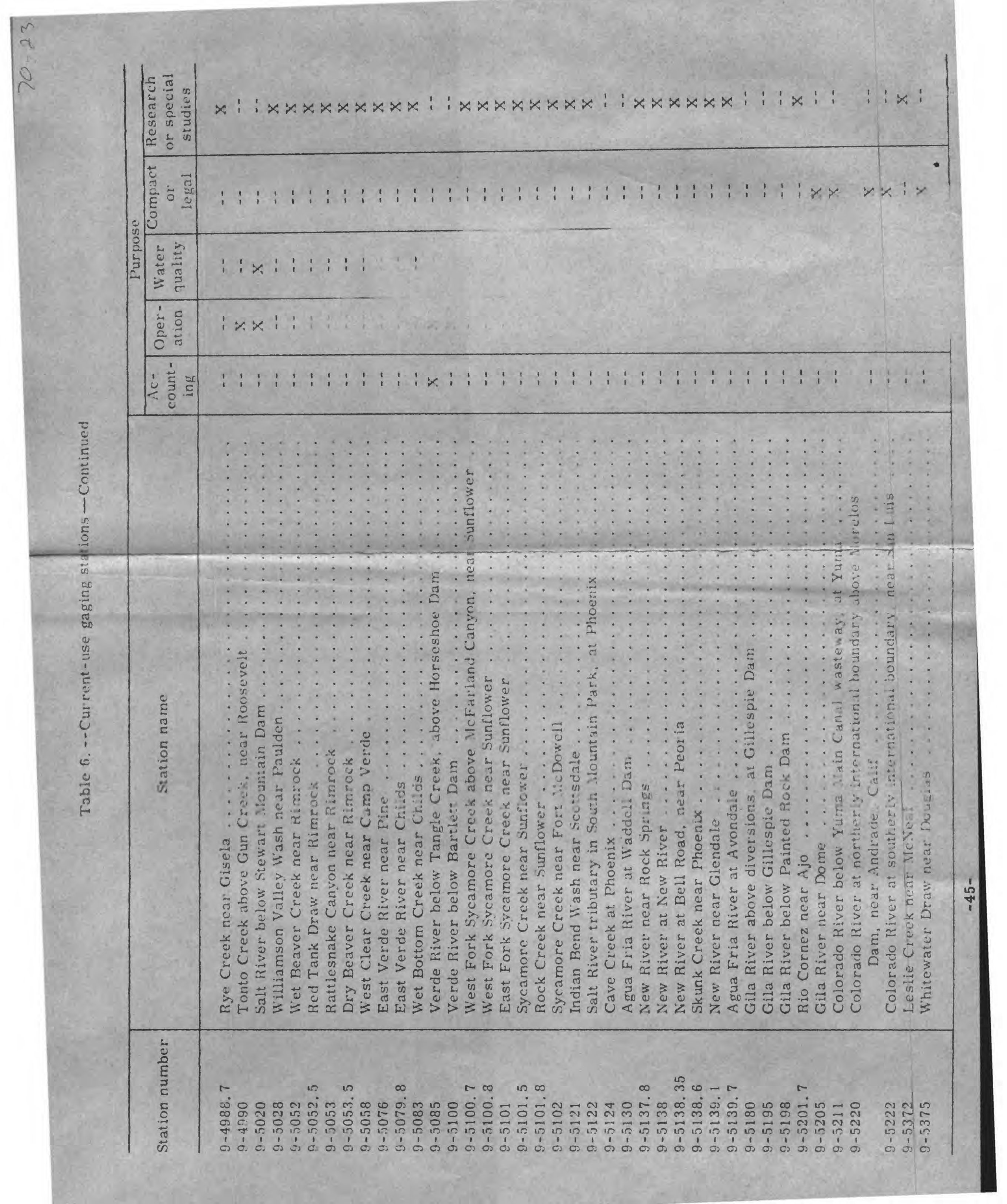




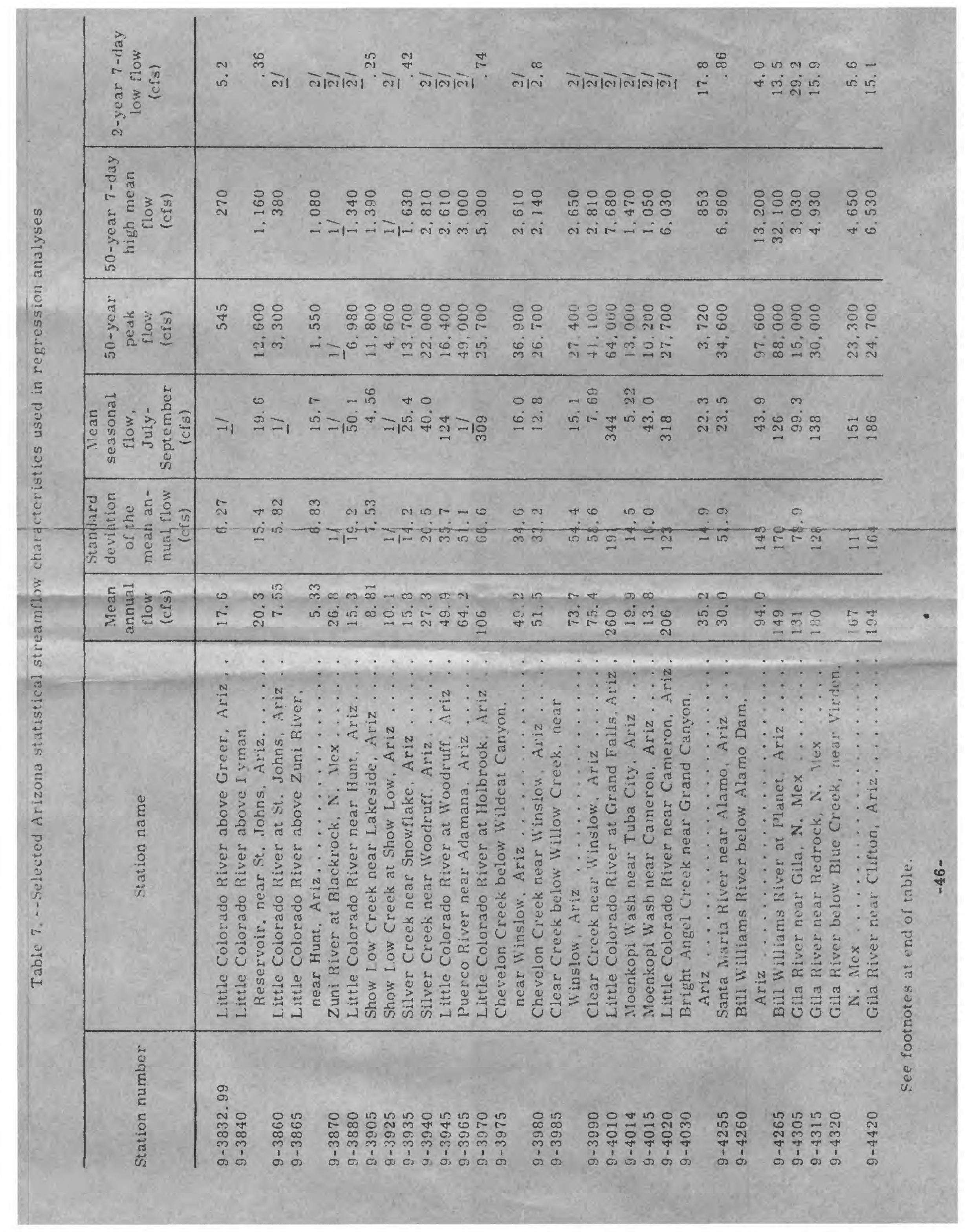




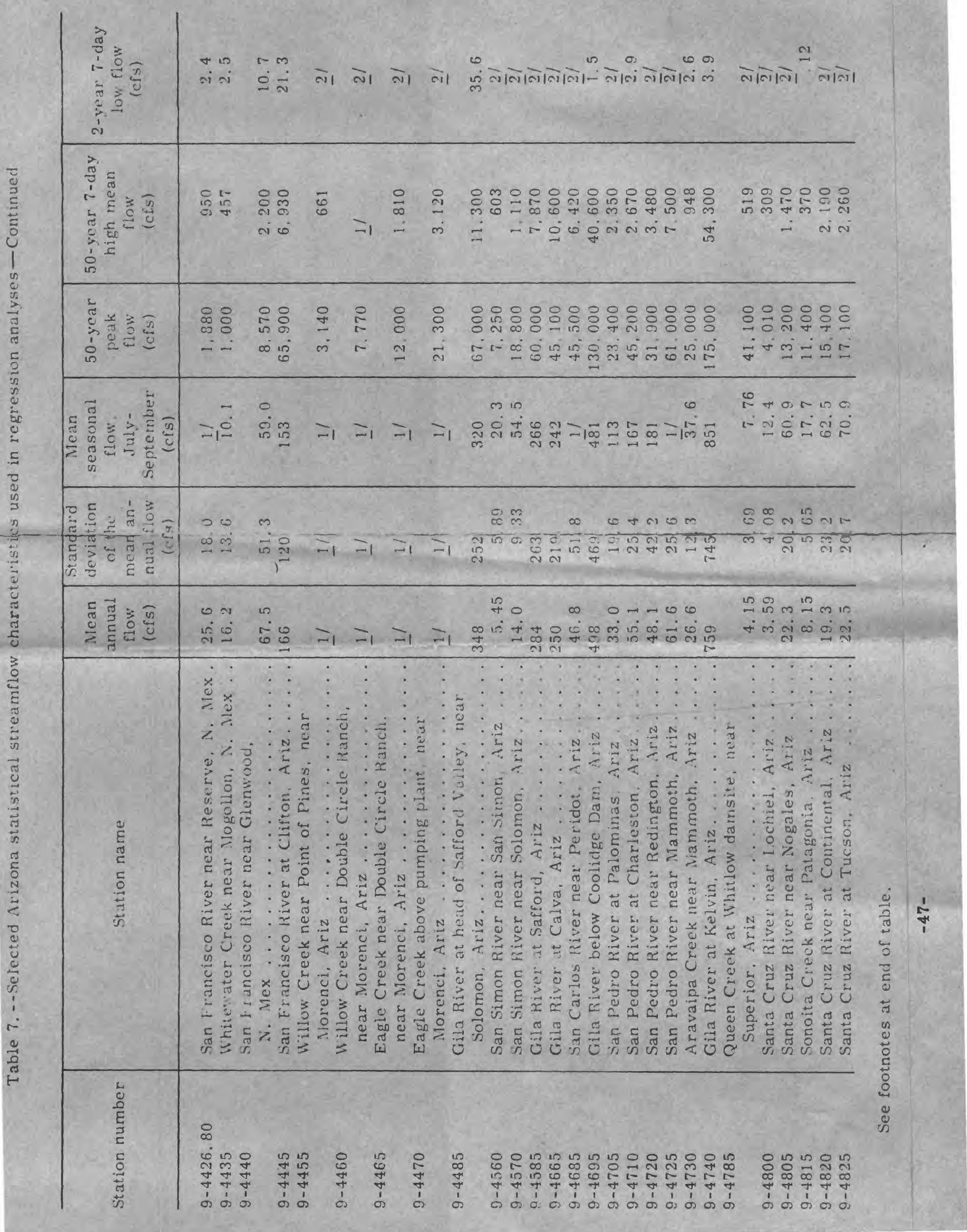




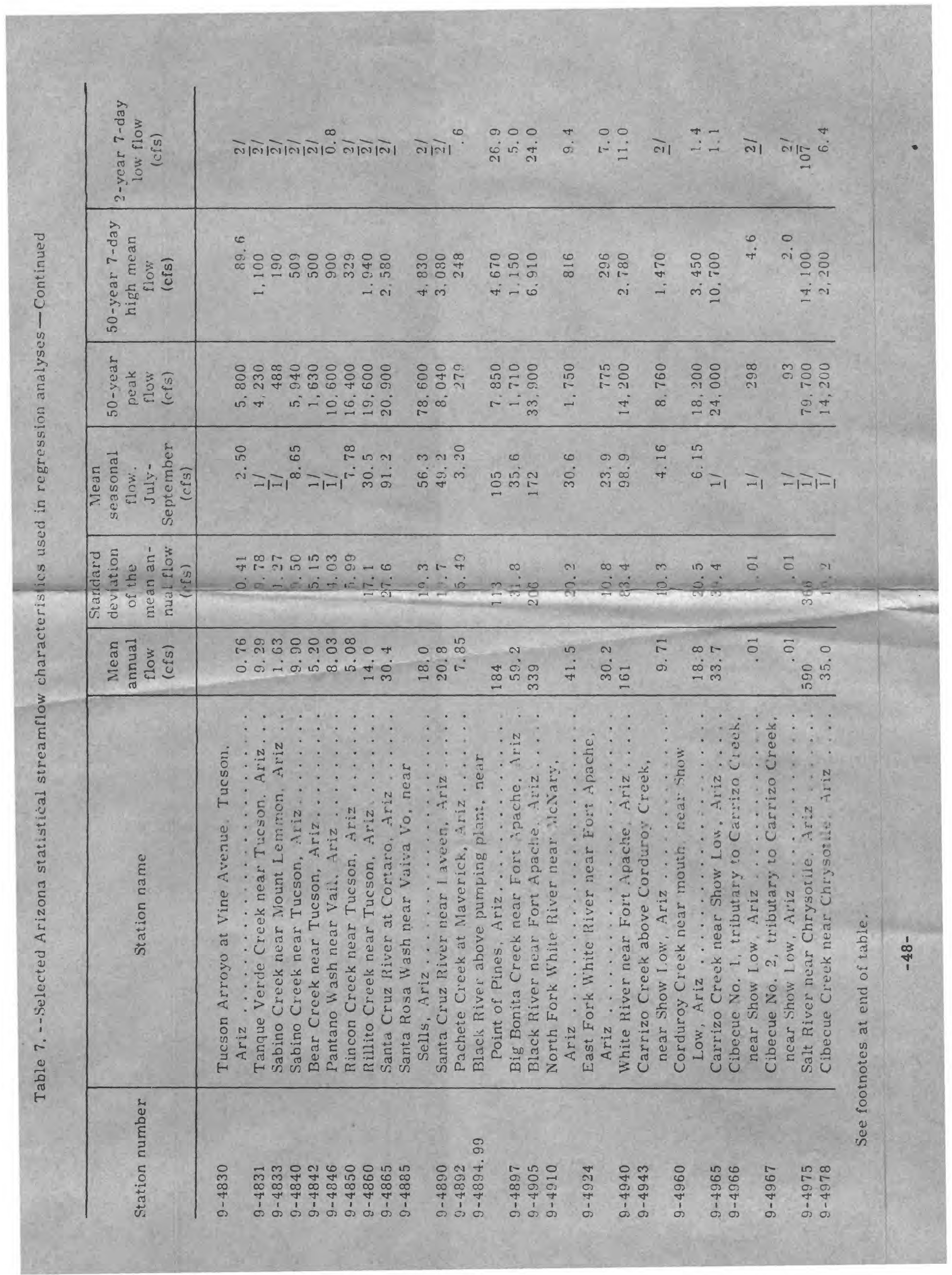




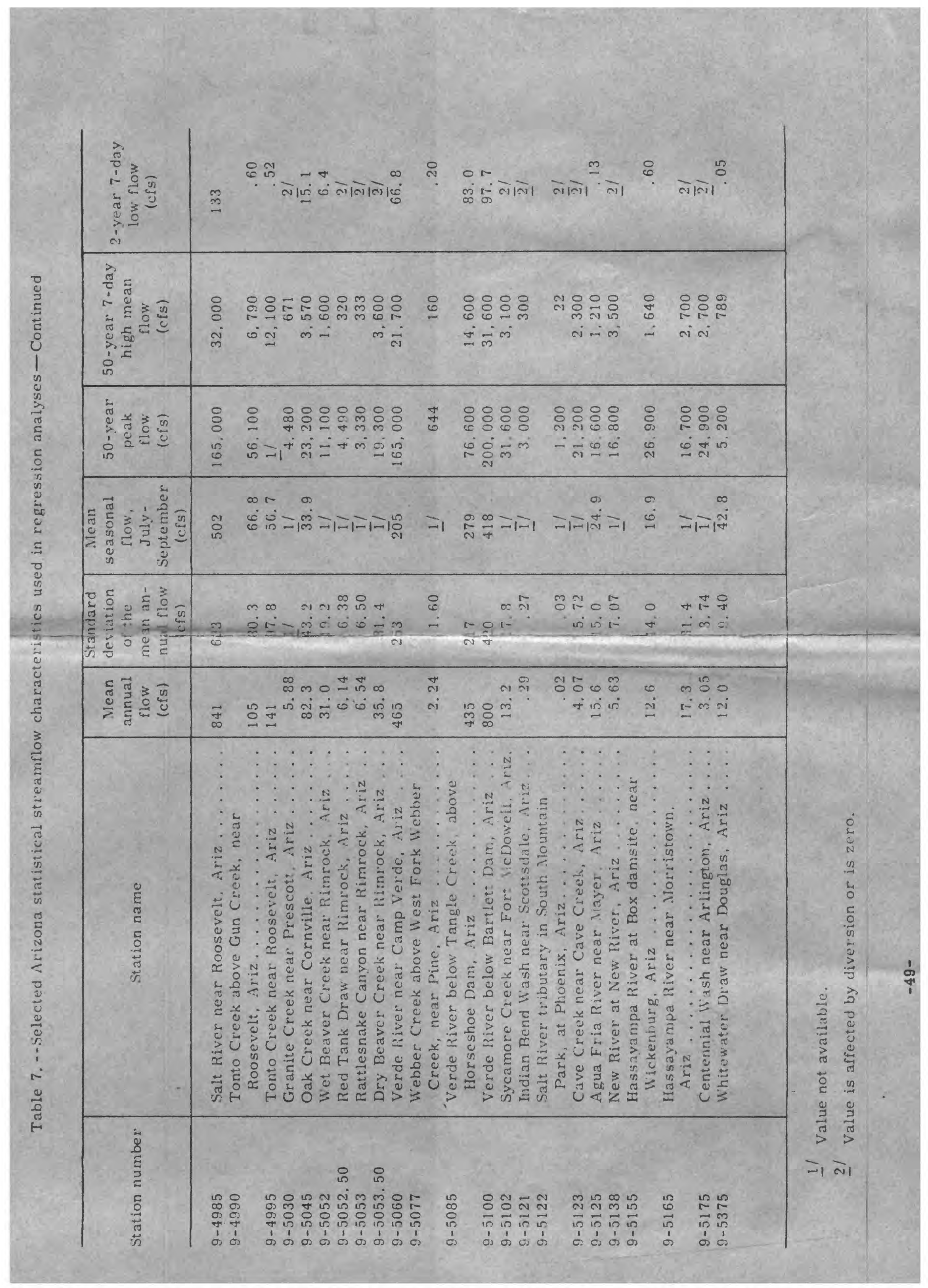

